$16^{\text {th }}$ International Conference on

AEROSPACE SCIENCES \& AVIATION TECHNOLOGY,

ASAT - 16 - May 26 - 28, 2015, E-Mail: asat@ mtc.edu.eg

Military Technical College, Kobry Elkobbah, Cairo, Egypt

Tel : +(202) 24025292 - 24036138, Fax: +(202) 22621908

\title{
Performance and Emission Analysis of a Diesel Engine Burning Biodiesel from Waste Cooking Oil
}

\section{M.S.Gad}

Abstract: Biodiesel has a vital role in recent years as an alternative fuel for diesel engines. Biodiesel was produced from waste cooking oil by transesterification process. Physical and chemical properties of biodiesel blends up to $20 \%$ were near to diesel fuel. The aim of this study to is to reuse biodiesel produced from waste cooking oil as a fuel and make a comparative study of performance parameters and exhaust emissions between biodiesel blends. Diesel- waste cooking oil biodiesel blends of 10 and $20 \%$ were prepared. Experimental investigations were tested in a four stroke, single cylinder, diesel engine at a constant speed of $1500 \mathrm{rpm}$ and variable loads. Diesel- biodiesel blends provided significant increase in fuel consumption, specific fuel consumption, exhaust gas temperature, $\mathrm{NO}_{\mathrm{x}}, \mathrm{CO}_{2}$ and oxygen concentrations about diesel fuel. Waste cooking oil biodiesel blends resulted in significant decrease in thermal efficiency, volumetric efficiency, air- fuel ratio, $\mathrm{CO}$ and $\mathrm{HC}$ emissions about diesel fuel. Performance characteristics and exhaust emissions concentrations for biodiesel blends were near to diesel fuel, so, we recommend using biodiesel blends up to $20 \%$ in diesel engines without engine modifications.

Keywords: Waste Cooking Oil, Biodiesel, Diesel Engine, Performance, Exhaust Emissions 1. Introduction

Waste cooking oil biodiesel was derived from waste cooking oil using transesterification process. Specific fuel consumption for biodiesel blend of B25 increased up to 5.69\% compared to diesel fuel. However, $\mathrm{HC}$ and $\mathrm{CO}$ emission reductions compared to diesel fuel were found to be around $16.24 \%$ and $19.81 \%$, respectively. But the amount of increase in $\mathrm{NO}_{\mathrm{x}}$ emissions for biodiesel blends reached up to $17.2 \%$. Transesterification process was used to reduce viscosity of waste cooking oil. Thermal efficiency for biodiesel blends up to B25 was slightly lower than those of diesel fuel. $\mathrm{CO}$ and $\mathrm{HC}$ emissions reduced when biodiesel blends up to $25 \%$ in diesel engines. The reductions in these exhaust emissions for waste cooking oil biodiesel were $11.66 \%$ and $23.12 \%$, respectively [1]. Waste cooking oil biodiesel fuel produced by transesterification of waste cooking oil had shown very promising chemical and physical properties compared with diesel fuel. Biodiesel of waste cooking oil B50 resulted in a considerable reduction in unburnt hydrocarbons associated with an increase in the $\mathrm{CO}_{2}$ and $\mathrm{NO}_{\mathrm{x}}$ emissions due to advance of fuel injection timing. Results indicated an increase in specific fuel consumption with simultaneous reduction in the engine thermal efficiency compared to conventional diesel fuel due to the oxygen content and the lower calorific value of biodiesel compared to diesel fuel [2]. Waste cooking oil methyl ester and its blends with diesel fuel of $20 \%, 40 \%, 60 \%$ and $80 \%$ had been studied. Biodiesel blends gave a reduction of carbon monoxide, hydrocarbon and increase in nitrogen oxides emissions. Engine performance reduced with increase in biodiesel percentage in the blend. The exhaust gas temperature for the blends was higher compared to that of standard diesel fuel. Emission of oxides of nitrogen from the waste cooking oil blend B40 is higher than that of diesel fuel. CO emission of the blend $\mathrm{B} 40$ is closer to the standard diesel fuel. $\mathrm{CO}_{2}$ emission is also lesser at the same conditions. The experimental result also proves that lower and medium percentages of waste cooking oil methyl ester can be substituted for diesel fuel [3].

* Researcher, Mechanical Engineering Department, National Research Centre, 33 El Behoos Street, El Dokki, Giza/ Email: mgad27@yahoo.com 
Five test fuels such as diesel fuel, waste cooking oil biodiesel B5, waste cooking oil biodiesel B20, and waste cooking oil biodiesel B30 were investigated. Experimental results indicate that hydrocarbons emissions reductions by $10.5 \%$ to $36.0 \%$, and carbon monoxide by $3.33 \%$ to $13.1 \%$ as compared diesel fuel. Specific fuel consumption was higher for biodiesel blends because of biodiesel having a lower heating value compared to diesel fuel [4]. Experiments were conducted on direct injection diesel engine using diesel fuel, biodiesel and their blends to investigate the exhaust emissions of the engine under different engine loads at an engine speed of $1800 \mathrm{rpm}$. Blended fuels containing 19.6\%, 39.4\%, 59.4\% and $79.6 \%$ by volume of biodiesel, corresponding to $2 \%, 4 \%, 6 \%$ and $8 \%$ by mass of oxygen in the blended fuel, were used. Biodiesel used in this study was converted from waste cooking oil. Specific fuel consumption and the thermal efficiency increase. The $\mathrm{HC}$ and $\mathrm{CO}$ emissions decrease while $\mathrm{NO}_{\mathrm{x}}$ emission increases [5]. Waste cooking oil biodiesel blends of B5 and B10 were tested and compared to diesel fuel. Biodiesel blends of B5 and B10 resulted in slightly increment on specific fuel consumption up to $4 \%$ and reduction on thermal efficiency up to $2.8 \%$. Biodiesel additions increased $\mathrm{NO}_{\mathrm{x}}$ emissions up to $8.7 \%$ and decreased of hydrocarbon emissions for the all engine loads. There were no significant changes on $\mathrm{CO}$ emissions at the low and medium engine loads, some reductions were observed at the full engine load. $\mathrm{CO}_{2}$ emissions were slightly increased for the all engine loads. $\mathrm{HC}$ emissions showed decreasing trend up to $5 \%$ for low and medium engine loads and up to $29 \%$ for the high engine load with the addition of the biodiesel fuel [6].

With increase percentage of waste cooking oil biodiesel in diesel-biodiesel blends, higher exhaust gas temperature of waste cooking oil biodiesel which increased with percentage increase of waste cooking oil biodiesel in the blend. A slight increase in $\mathrm{NO}_{\mathrm{x}}$ was produced when compared to diesel at rated load. This was due to higher oxygen content of biodiesel and its blends. $\mathrm{CO}$ and $\mathrm{HC}$ emissions were found to significantly decrease with biodiesel and its blends due to a more complete combustion caused by higher oxygen content. An increase in specific consumption had been found when using biodiesel blends compared to diesel fuel due to the lower heating value of biodiesel and its blends. There was a decrease in thermal efficiency with increase in percentage of biodiesel in biodiesel blends [7, 8, 9, 10]. Waste cooking oil ethyl ester was prepared by transesterification using potassium hydroxide as catalyst and was used in diesel engine. Tests were carried out at a rated speed of $1500 \mathrm{rpm}$ at different loads. Vegetable oils pose operational and durability problems when subjected to long term usages in diesel engines. These problems are attributed to high viscosity and low volatility of vegetable oils. Transesterification was found to be an effective method of reducing vegetable oil viscosity and eliminating operational and durability problems. The exhaust gas temperature increased with increasing biodiesel concentration. Waste cooking oil ethyl ester blends showed performance characteristics close to diesel fuel. Although waste cooking oil biodiesel heating value is lower that of diesel fuel by about $15 \%$. Blend B10 exhibits a heating value about $45.50 \mathrm{MJ} / \mathrm{kg}$ is only $2 \%$ lower than that of diesel fuel. $\mathrm{NO}_{\mathrm{x}}$ emission for waste cooking oil biodiesel is same as that of diesel fuel at lower loads and slightly higher at full loads [8]. A diesel engine test using waste cooking biodiesel fuel was run to engine performance and exhaust emissions of diesel engine. By adding $20 \%$ of waste vegetable oil methyl ester, the concentration of the $\mathrm{CO}$ and $\mathrm{HC}$ emissions were significantly decreased when biodiesel was used $[11,12,13,14]$.

The aim of this work is to reuse waste cooking oil as a biodiesel in diesel engines. Physical and chemical properties of biodiesel blends up to $20 \%$ were near to diesel fuel. Comparison of performance characteristics such as fuel consumption, specific fuel consumption, thermal efficiency, exhaust gas temperature, volumetric efficiency and air- fuel ratio for D100, B10 and B20 were investigated. Exhaust emissions concentrations such as $\mathrm{CO}, \mathrm{CO}_{2}, \mathrm{NO}_{\mathrm{x}}, \mathrm{HC}$ and $\mathrm{O}_{2}$ of B10 and B20 were compared to diesel oil. Performance characteristics and exhaust 
emissions concentrations for biodiesel blends were near to diesel fuel, so, we recommend using biodiesel blends up to $20 \%$ in diesel engines without engine modifications.

\section{Waste Cooking Oil Biodiesel Production}

Waste cooking oil has sufficient potential to run diesel engines. It is available in the local market at cheaper rate. Huge quantities of waste cooking oil can be collected from restaurants and food item industry. Viscosity of waste cooking oil is about ten times, greater and its density is about $10 \%$ higher than that of diesel fuel. Transesterification process is used to reduce the viscosity of waste cooking oils and converting it to biodiesel. Biodiesel is derived from vegetable oils or animal fats which are basically long chain triglyceride esters with free fatty acids. The long chain triglyceride ester is converted into mono ester by the process called transesterification. In this process, the vegetable oils were reacted with methanol or ethanol in the presence of acid or base catalyst producing fatty acids methyl or ethyl ester. In this study, used cooking oil was transesterified using 1\% sodium hydroxide and $20 \%$ methanol at the temperature range of $65-69 \mathrm{C}$. The reaction time was two hours and conversion efficiency was $92.5 \%$. Properties of waste cooking oil biodiesel such as density, viscosity, heating value and flash point were measured in Egyptian Research Petroleum Institute, Cairo and were indicated in Table $1[10,11,12]$.

Table 1. Properties of waste cooking oil biodiesel, diesel fuel and their blends.

\begin{tabular}{|l|c|c|c|}
\hline Properties & Diesel & B20 & B100 \\
\hline Density $\left(\mathrm{kg} / \mathrm{m}^{3}\right)$ & 830 & 841 & 885 \\
\hline Kinematic Viscosity $\left(\mathrm{mm}^{2} / \mathrm{sec}\right)$ at $40^{\circ} \mathrm{C}$ & 3.05 & 4.9 & 12.5 \\
\hline Flash Point ${ }^{\circ} \mathrm{C}$ & 65 & 74 & 179 \\
\hline Heating Value $(\mathrm{MJ} / \mathrm{kg})$ & 42 & 41.25 & 38.6 \\
\hline
\end{tabular}

\section{Experimental Set up}

The present study was carried out to investigate the performance and emission characteristics of biodiesel derived from waste cooking oil blends with diesel fuel in diesel engine and compared to diesel fuel. The test engine is a Kirloskar make, single cylinder, four stroke, water cooled, direct injection, AV1 model diesel engine. Its specifications are given in Table 2. The engine was connected to an eddy current dynamometer to measure the power output and speed. The engine was equipped to measure fuel consumption, engine speed and exhaust gas temperature. The engine receives air through an air box fitted with an orifice for measuring the air consumption. A pressure differential meter is used to measure the difference in pressure between the two sides of the orifice. Fuel consumption rate was determined using a glass burette and stop watch. The engine speed was measured using a digital tachometer. MRU DELTA 1600-V exhaust gas analyzer was used for measuring the exhaust gas emission concentrations of $\mathrm{CO}, \mathrm{HC}, \mathrm{CO}_{2}, \mathrm{O}_{2}$ and $\mathrm{NO}_{\mathrm{x}}$. A data acquisition card (National Instrument 6210) was used to acquire data to be fed to personal computer. The schematic diagram of experimental set up and test rig is shown in Fig.1. The engine was warmed up before taking all readings. When the engine reached its stable condition, the experiments were started and measurements recorded. The engine was then operated with blends of diesel and waste cooking oil biodiesel (B10 and B20). For every operating condition, the engine speed was checked and maintained constant at rated speed of $1500 \mathrm{rpm}$. The performance parameters and exhaust gas emissions investigated were fuel consumption, specific fuel consumption, thermal efficiency, exhaust gas temperature, volumetric efficiency, air- fuel ratio, carbon dioxide $\left(\mathrm{CO}_{2}\right)$, carbon monoxide $(\mathrm{CO})$, nitrogen oxides $\left(\mathrm{NO}_{\mathrm{x}}\right)$, unburned hydrocarbons $(\mathrm{HC})$ and oxygen $\left(\mathrm{O}_{2}\right)$ concentrations. 
Table 2. Test Engine Specifications.

\begin{tabular}{|r|r|}
\hline Engine parameters & Specifications \\
\hline Type & Kirloskar \\
\hline Number of cylinders & Single \\
\hline Cycle & Four stroke \\
\hline Cooling & Water \\
\hline Cylinder diameter $(\mathrm{mm})$ & 85 \\
\hline Piston stroke $(\mathrm{mm})$ & 110 \\
\hline Compression ratio & $17.5: 1$ \\
\hline Governing speed & $1500 \mathrm{rpm}$ \\
\hline Rated power (HP) & 6.5 \\
\hline
\end{tabular}
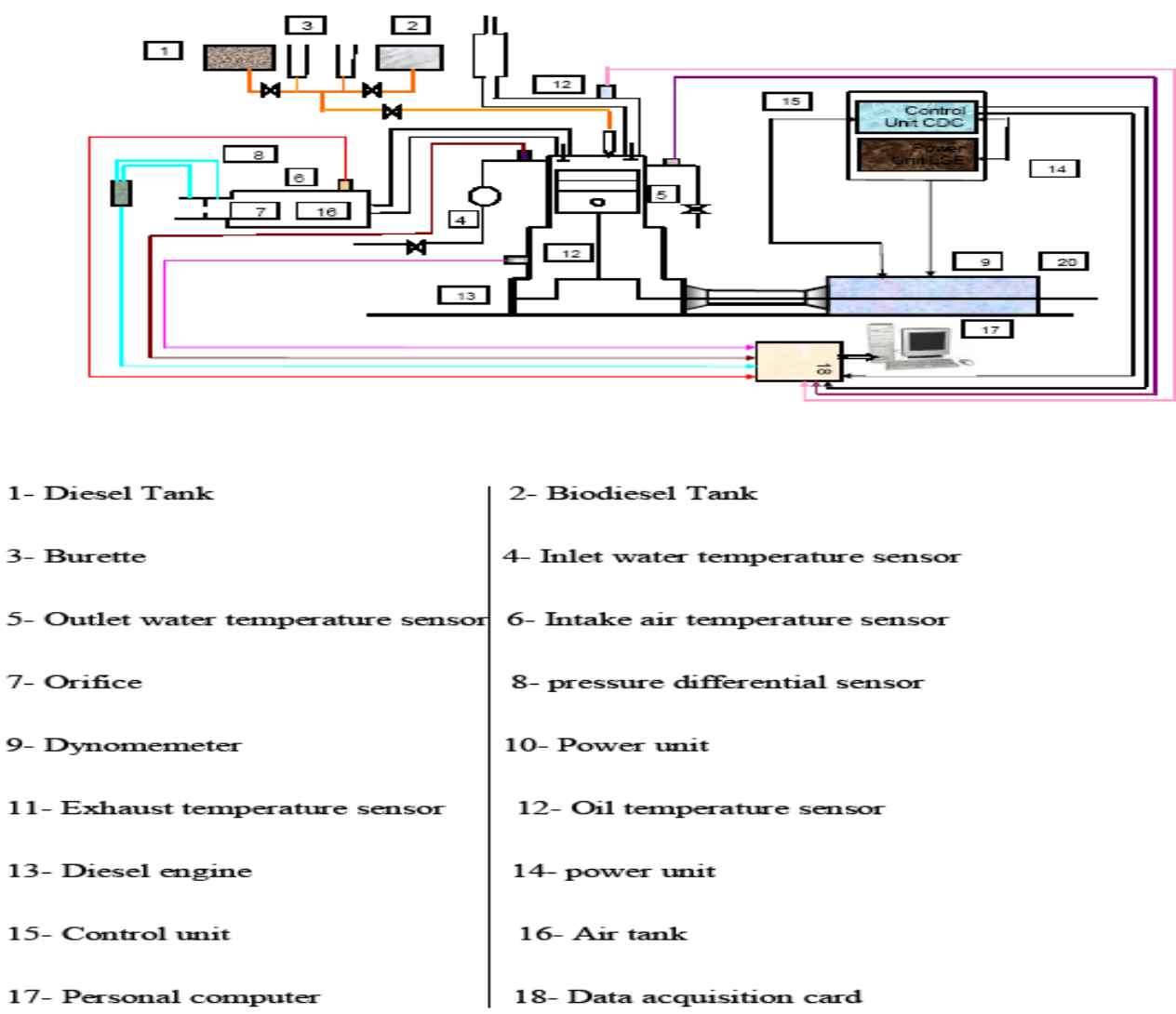

Fig.1. Schematic Diagram of a diesel Test Engine fueled withDiesel and Biodiesel Blends.

\section{Results and Discussion}

\subsection{Fuel Consumption}

The variation of fuel consumption with brake power is shown in Fig.2. It is observed that as the load increased, fuel consumption increased for all the fuels. This variation increased from lower loads to higher loads due to the increase in injected fuel with the increase in output power. As percentage of biodiesel increases, the fuel consumption tends to increase because of lower heating value of biodiesel. At full load, the maximum increase in fuel consumption for blend B10 and B20 in comparison with diesel fuel was about 1.4 and $2.6 \%$, respectively. The deviations of fuel consumption for biodiesel blends were insignificant. Above results are confirmed with these references $[12,13]$. 


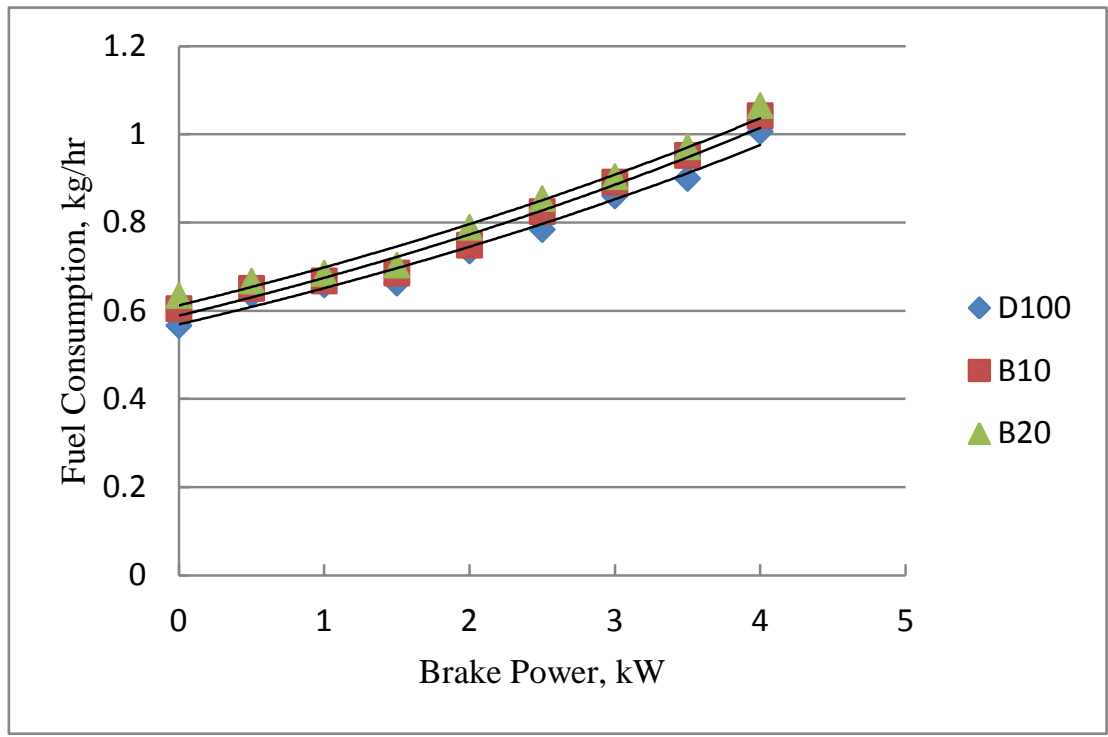

Fig.2. Variation of Fuel Consumption with Brake Power for biodiesel blends.

\subsection{Specific Fuel Consumption}

Variation of specific fuel consumption with brake power for diesel and diesel- biodiesel blends was shown in Fig.3. Specific fuel consumption decreased with the increase in load for all fuels due to increase of fuel consumption with load. Specific fuel consumption for biodiesel blends was higher than diesel fuel. This may be due to higher fuel density, higher viscosity and lower heating value of biodiesel compared to diesel fuel and this leads to lower heat content. At full load, the highest value of specific fuel consumption for blend B10 and B20 in comparison with diesel fuel was about 1.3 and $2.2 \%$, respectively. The changes of specific fuel consumption for biodiesel blends were insignificant. These results are confirmed by references $[13,14,15,16,17,18,19]$.

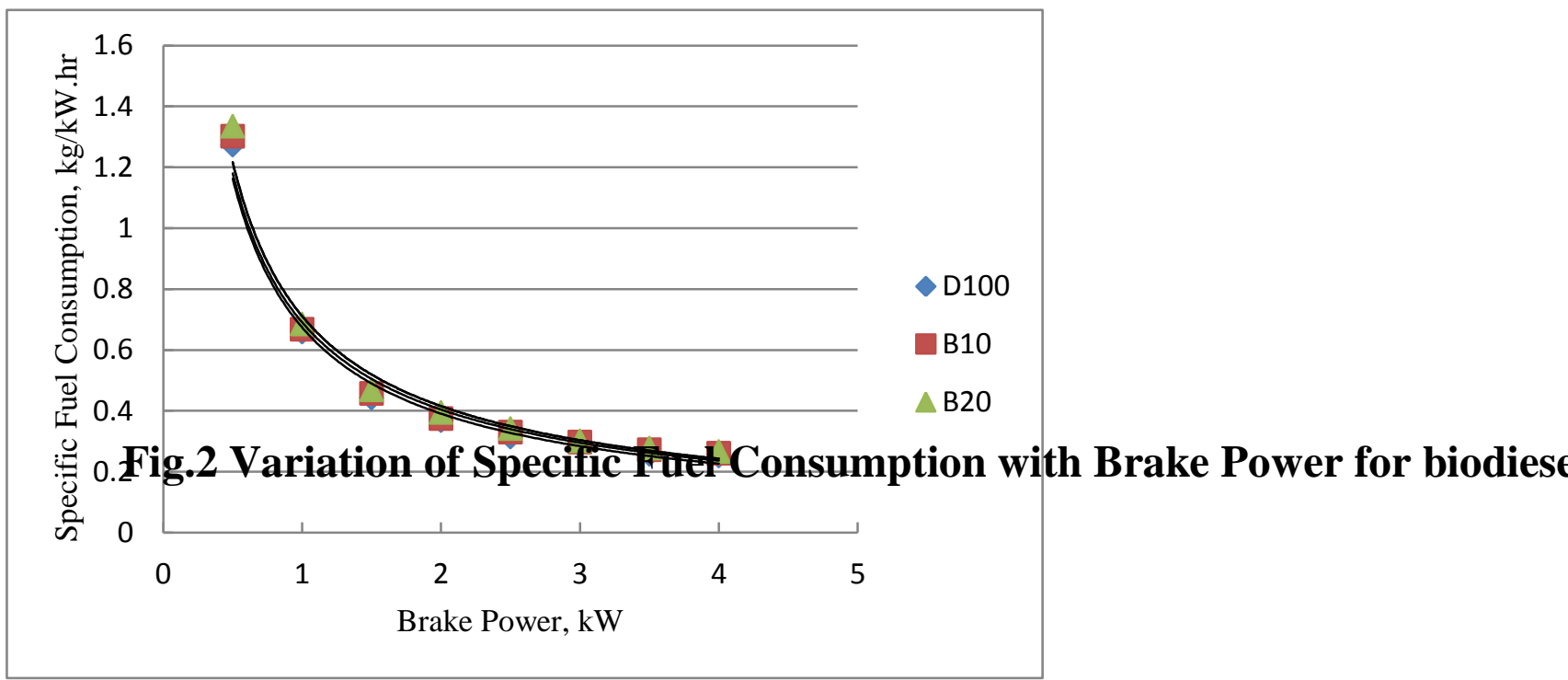

Fig.3. Variation of Specific Fuel Consumption with Brake Power for biodiesel blends.

\subsection{Thermal Efficiency}

The variation of thermal efficiency with brake power for diesel and diesel- biodiesel blends was shown in Fig.4. Thermal efficiency was having tendency to increase with increase in engine load. This was due to the reduction in heat loss and increase in power developed with 
increase in engine load. Thermal efficiency for biodiesel blends was lower than diesel fuel. This may be due to poor atomization, higher viscosity and reduction in heat loss of biodiesel blends compared to diesel fuel. Decrease of thermal efficiencies of biodiesel blends compared to diesel fuel was due to higher fuel consumption and lower heating value of biodiesel. At full load, the maximum decrease in thermal efficiency for B10 and B20 about diesel fuel was 2.5 and $3.5 \%$, respectively. The deviations of thermal efficiency for biodiesel blends were not considered. The above results are in agreement with the results reported by other researchers $[14,15,16,17,18,19,20]$.

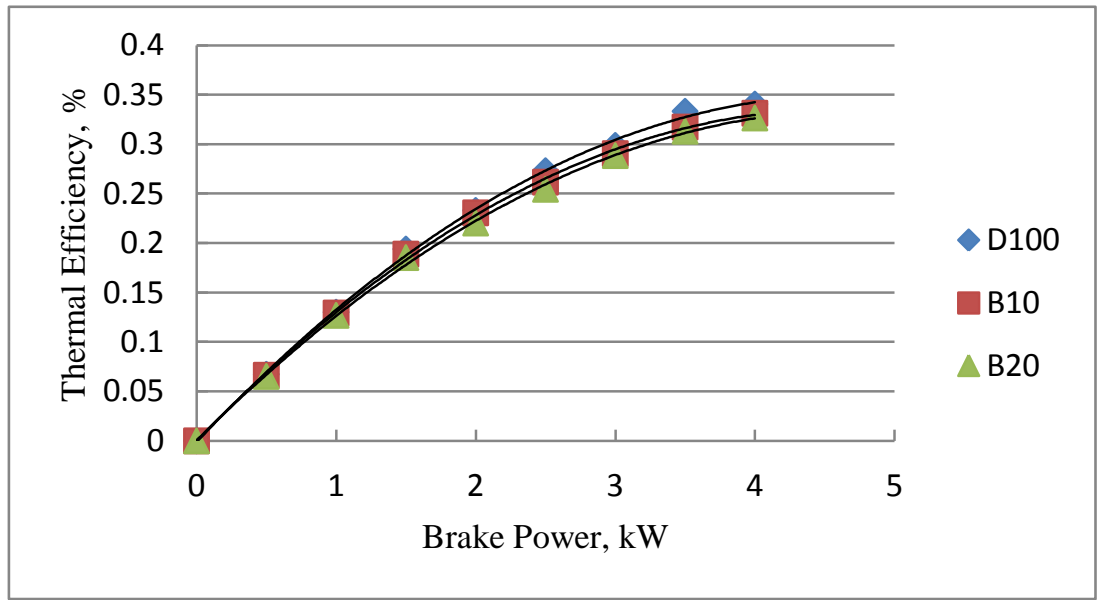

Fig.4.Variation of Thermal Efficiency with Brake Power for biodiesel blends.

\subsection{Exhaust Gas Temperature}

Figure 5 showed the variation of exhaust gas temperature with brake power for diesel and diesel- biodiesel blends. As load increased, exhaust gas temperature increased for all fuels. At full load, the chemically correct ratio of air and fuel was used and high heat was generated. Exhaust gas temperatures for all biodiesel blends were higher than diesel fuel due to the higher viscosity of biodiesel and the oxygen content. For biodiesel blends, the combustion was delayed due to higher physical delay period. As the combustion was delayed, injected biodiesel fuel molecules may not get enough time to burn completely before top dead centre, hence some fuel- air mixtures tended to burn during the early part of expansion, consequently after burning occurred and the exhaust gas temperature increased. At full load, values of exhaust gas temperatures for diesel, B10 and B20 fuels were 355,370 and $380^{\circ} \mathrm{C}$. The deviations of exhaust gas temperatures for biodiesel blends were insignificant. These results are confirmed with these references $[8,11,16]$. 


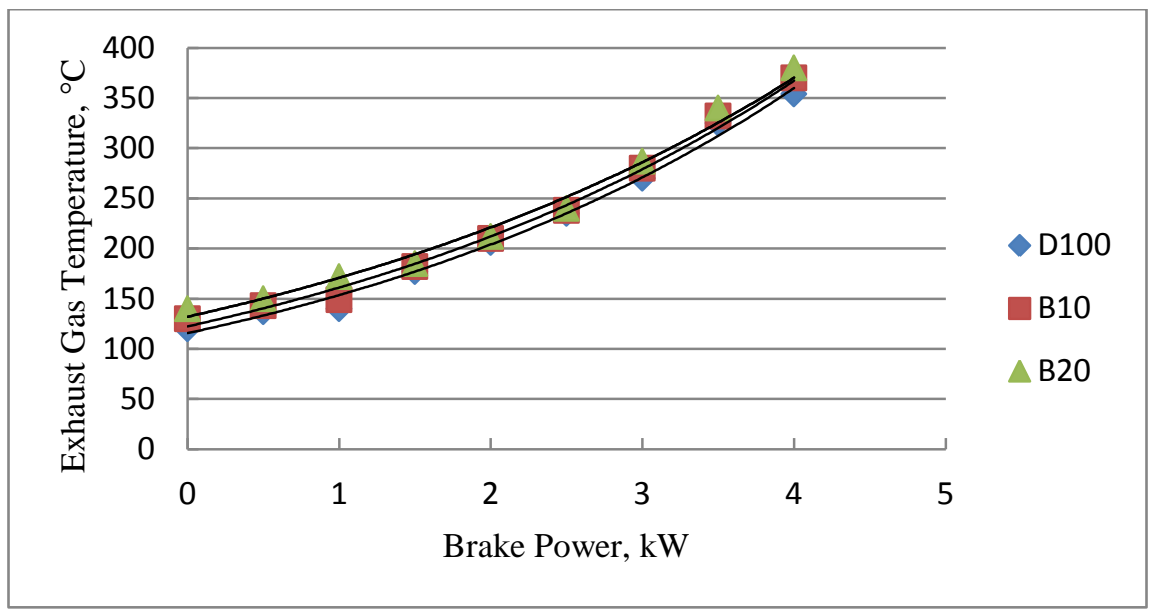

Fig.5 Variation of Exhaust Gas Temperature with Brake Power for biodiesel blends.

\subsection{Volumetric Efficiency}

In Fig.6, variation of volumetric efficiency with engine load was shown. The volumetric efficiency increased with the increase in engine load. This was due to the decrease in air density associated with higher engine temperature and load. At higher loads, higher engine temperature about ambient temperature may cause reductions in air density. It was seen that volumetric efficiencies were lower for diesel- biodiesel blends compared to diesel fuel. Volumetric efficiency decreased with the increase in biodiesel percentage in biodiesel blends. Oxygen content in waste cooking biodiesel is about $11 \%$ which decreased the amount of air needed for complete combustion. At full load, the maximum decrease in volumetric efficiency for B10 and B20 about diesel fuel is 3.5 and $8 \%$, respectively.

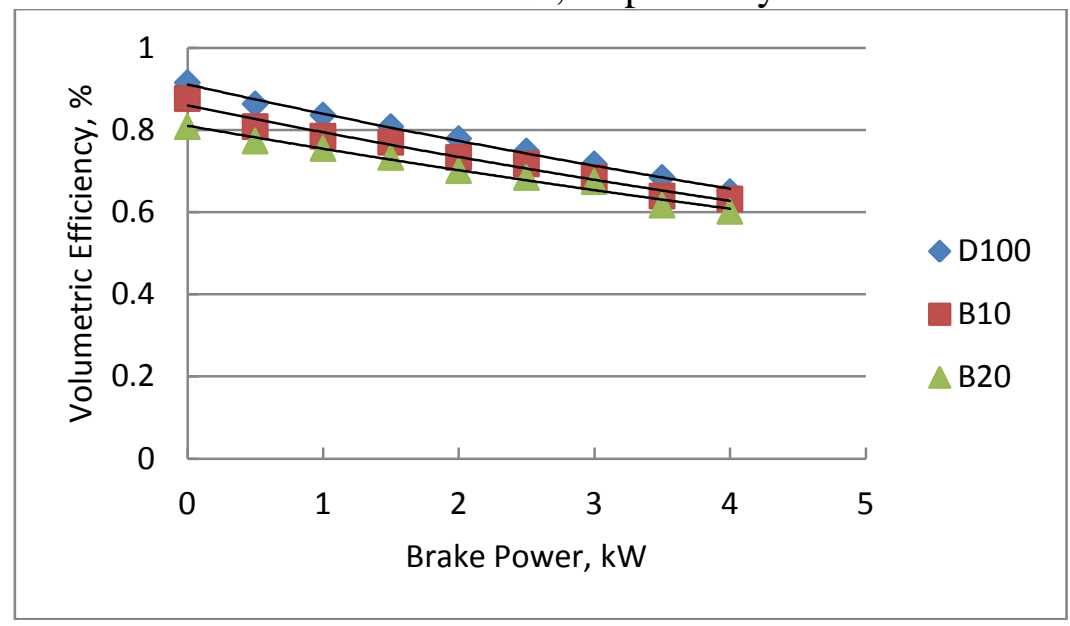

Fig.6. Variation of Volumetric Efficiency with Brake Power for Biodiesel Blends.

\subsection{Air- Fuel Ratio}

The variation air-fuel ratio with load for diesel and biodiesel blends was shown in Fig.7. A richer mixture was needed at higher loads. Air- fuel ratio decreased with the increase in load due to the increase in mass of fuel and the compensation of load with increasing the amount of fuel injected. Fuel consumptions were higher for biodiesel blends compared to diesel fuel hence air-fuel ratio decreased. Oxygen content in waste cooking biodiesel is about $11 \%$, so, the amount of air needed for complete combustion decreased. Air- fuel mixing process was affected by the problems appear in atomization of biodiesel due to its higher viscosity. At full load, the maximum decrease in air- fuel ratio for B10 and B20 were about diesel fuel is 4.5 and $11 \%$. 


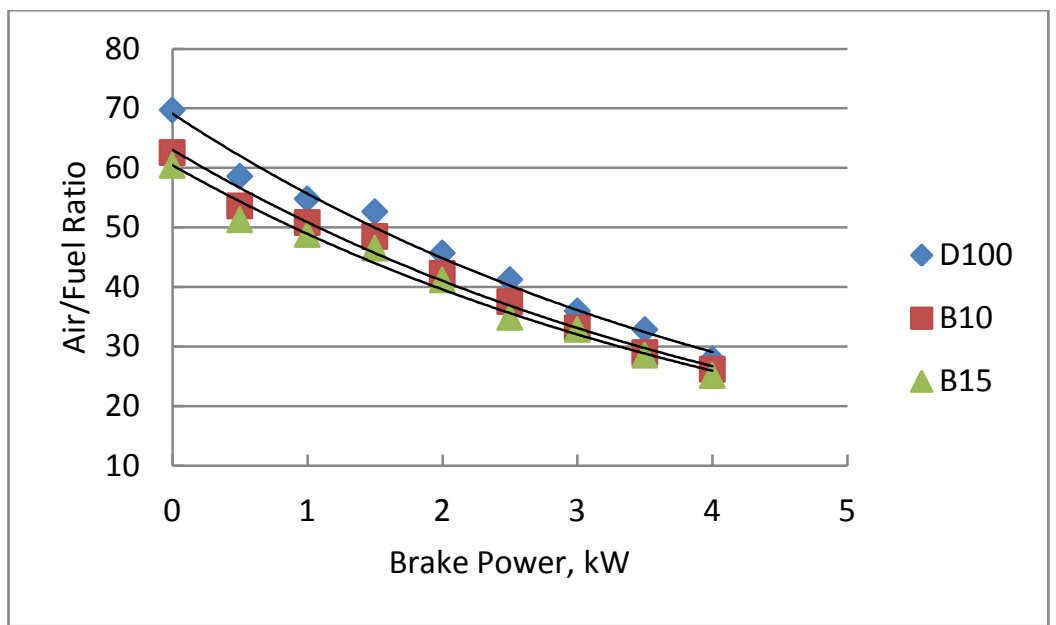

Fig.7. Variation of Air- Fuel Ratio with Brake Power for Biodiesel Blends.

\section{Engine Exhaust Emissions}

\subsection{Carbon Dioxide Emission}

It can be observed from Fig. 8 that the amount of $\mathrm{CO}_{2}$ emission increased with the increase of engine load due to higher fuel consumption at higher loads. Lower percentages of $\mathrm{CO}_{2}$ emissions were produced when diesel engine fueled with biodiesel blends compared to diesel fuel. This was due to the lower carbon to hydrogen ratio in biodiesel blends compared to diesel fuel. Diesel fuel has $85 \%$ carbon atoms while biodiesel has about $76 \%$. Biodiesel had oxygen content which improved combustion. B20 and B10 produced very low levels of $\mathrm{CO}_{2}$ emissions. Using higher concentrations of biodiesel, $\mathrm{CO}_{2}$ emission levels were lower than that of diesel fuel. At full load, the values of $\mathrm{CO}_{2}$ emissions for diesel, B10 and B20 fuels were $6.5,6.3$ and $6.2 \%$, respectively. The above results are in agreement with other researchers [13, $17,19,20,22]$.

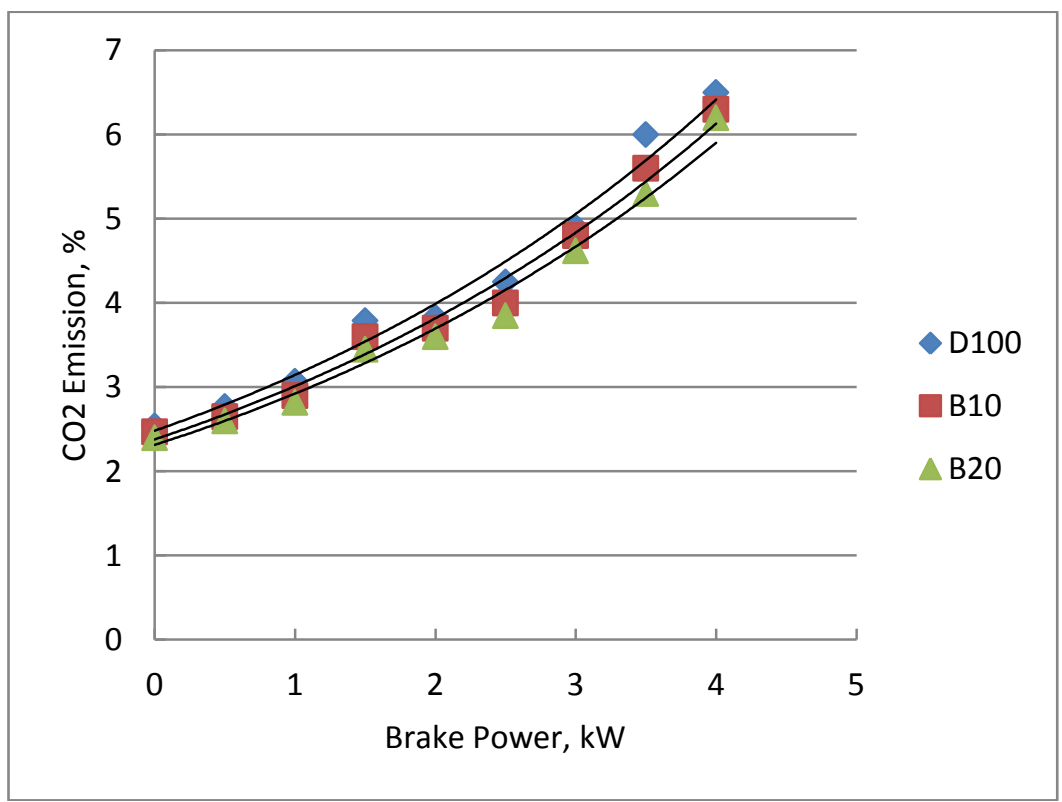

Fig.8. Variation of $\mathrm{CO}_{2}$ Emission with Brake Power for biodiesel blends 


\subsection{Carbon Monoxide Emission}

Carbon monoxide emissions of diesel and waste cooking oil biodiesel blends are shown in Fig. 9. CO emissions increased with the increase in load due to decrease of air- fuel ratio at higher loads. The higher combustion temperature at lower engine loads contributed to the general decreasing trend of $\mathrm{CO}$ emission. The decrease in carbon monoxide emission for biodiesel blends was due to more oxygen molecule present in the fuel, improved atomization and better vaporization of biodiesel resulting in complete combustion as compared to diesel fuel. The higher amount of oxygen in biodiesel will promote further oxidation of $\mathrm{CO}$ emission. At full load, CO emission for B10 and B20 blends were about 6 and 18\% lower than that of diesel fuel. The above results are closer to the results reported by other researchers [13, 14, 16, 19, 20, 21 and 22].

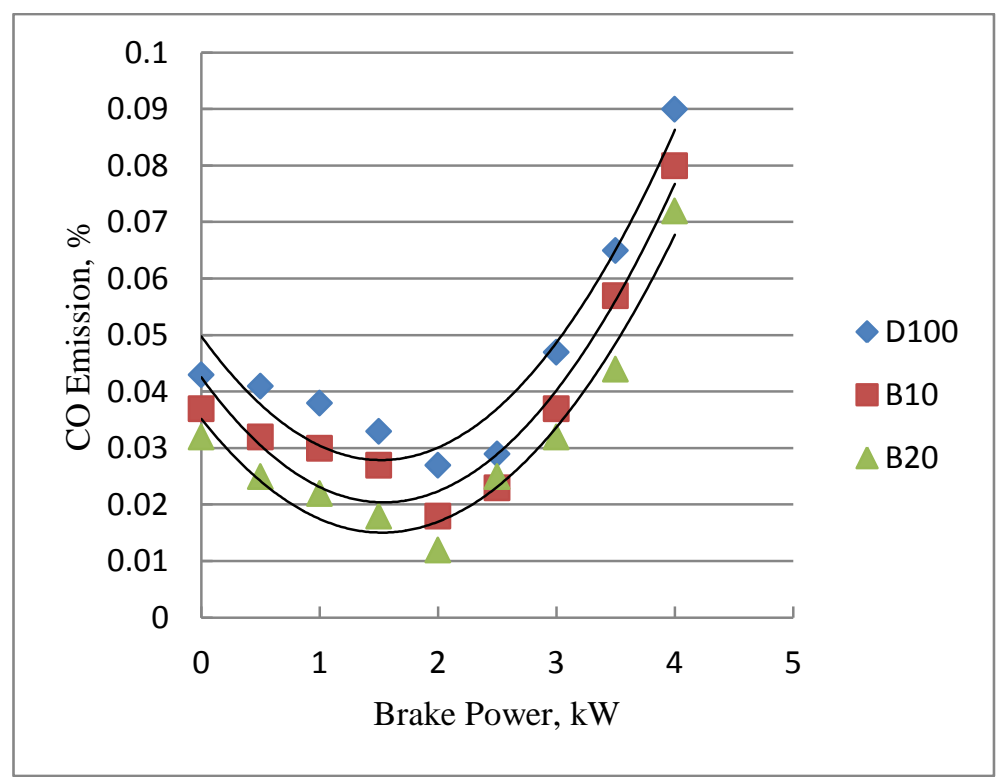

Fig.9.Variation of CO Emission with Brake Power for biodiesel blends.

\subsection{Nitrogen Oxide Emission}

Concentrations of $\mathrm{NO}_{\mathrm{x}}$ emissions variation with brake power are shown in Fig.10. $\mathrm{NO}_{\mathrm{x}}$ emission increased as the load increased due to higher combustion chamber temperature and higher fuel consumption. $\mathrm{NO}_{\mathrm{x}}$ emissions of biodiesel blends increased with the increase of biodiesel percentage. $\mathrm{NO}_{\mathrm{x}}$ emission is a function of oxygen inside the combustion chamber, combustion flame temperature and reaction time. Oxygen concentration in biodiesel blends might have caused the formation of $\mathrm{NO}_{\mathrm{x}}$ emissions. Furthermore, the increase of $\mathrm{NO}_{\mathrm{x}}$ emission was due to the higher cetane number of biodiesel which will reduce the ignition delay and higher combustion chamber temperature. Premix combustion of biodiesel blends led to higher emissions of $\mathrm{NO}_{\mathrm{x}}$. From diesel to $\mathrm{B} 20, \mathrm{NO}_{\mathrm{x}}$ emission increased. The peak concentrations at full load were $625 \mathrm{ppm}, 630 \mathrm{ppm}$ and $650 \mathrm{ppm}$ for diesel, B10 and B20, respectively. The above results are in agreement with other researchers $[13,14,16,18,19,20$ and 21]. 


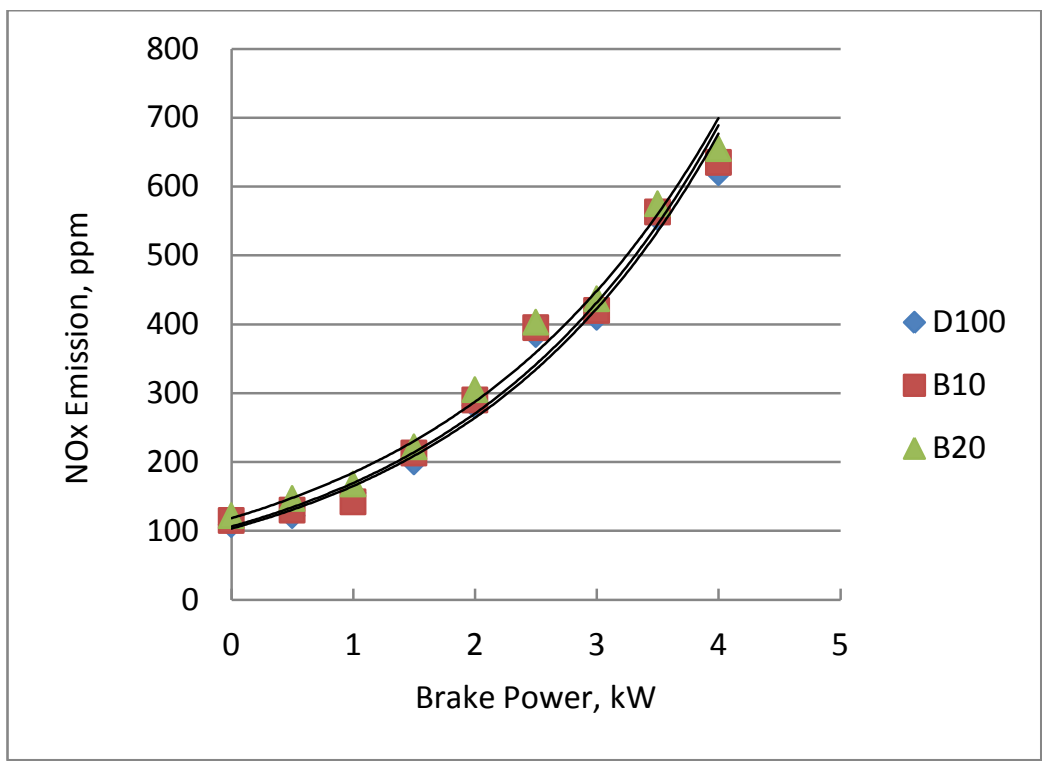

Fig.10.Variation of NOx Emission with Brake Power for biodiesel blends.

\subsection{Hydrocarbons Emissions}

Variations of $\mathrm{HC}$ emissions for diesel and biodiesel blends are shown in Fig. 11. HC emissions increased as the engine load increased due to the increase of fuel consumption at higher loads. Higher cetane number of waste cooking oil biodiesel resulted decrease in HC emission due to shorter ignition delay. Lower HC emissions of biodiesel blends were due to the presence of fuel bound oxygen and warmed up conditions. The maximum concentrations of $\mathrm{HC}$ are $32 \mathrm{ppm}, 27 \mathrm{ppm}$ and $23 \mathrm{ppm}$ for diesel, B10 and B20 fuels, respectively. . The above results are closer to the results reported by other researchers [13, 14, 17, 19, 20, 21, 22].

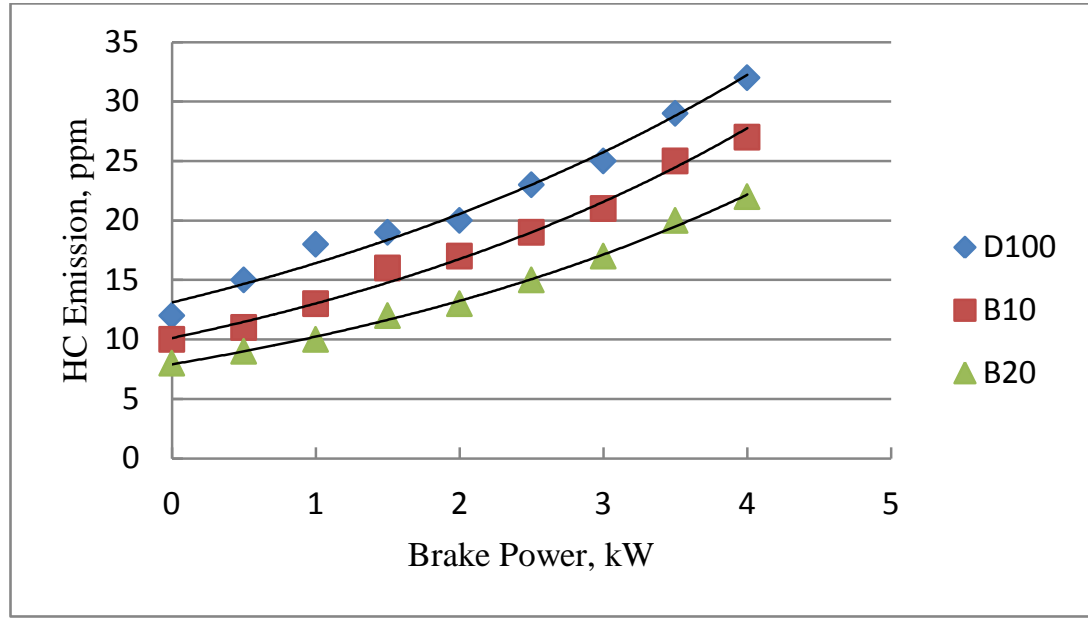

Fig.11. Variation of HC Emission with Brake Power for biodiesel blends.

\subsection{Oxygen Concentration}

The variation of oxygen concentration with brake power was shown in Fig.12. There is around $10 \%$ oxygen in the chemical structure of waste cooking oil biodiesel. A high amount of oxygen in biodiesel improved combustion and thus provided complete combustion. The observed decrease in oxygen content in the exhaust with increase in load may be due to richer mixture being burnt in the engine cylinder. The higher cylinder temperature led to produce a larger portion of oxygen which reacted with nitrogen and carbon to form $\mathrm{CO}, \mathrm{NO}_{\mathrm{x}}$ and $\mathrm{CO}_{2}$ at higher loads. Hence less oxygen was released to the atmosphere. It can also be observed that 
the oxygen concentrations increased with increase in biodiesel percentage in diesel- biodiesel blends. The increase in oxygen concentration with increase in blend proportion may be due to the inherent oxygen present in biodiesel. It can be noted that the percentage of oxygen in the exhaust was maximum for biodiesel blends and it decreased for other biodiesel blends in the order B20, B10 and diesel fuel. The maximum increase of oxygen concentration for B20 and B10 in comparison with diesel fuel was about 3 and $1 \%$, respectively. These results are confirmed with these references $[1,9]$.

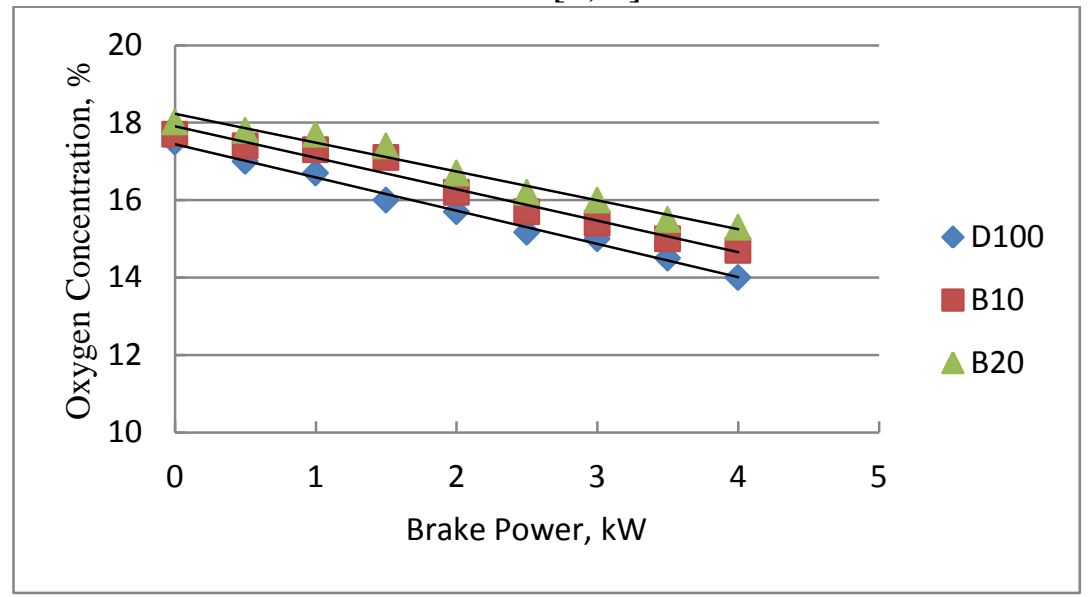

Fig.12.Variation of Oxygen Concentration with Brake Power for biodiesel blends.

\section{Conclusions}

The aim of this work is to reuse waste cooking oil as a biodiesel in diesel engines. Physical and chemical properties of biodiesel blends up to $20 \%$ were near to diesel fuel. Waste cooking oil biodiesel blends of 10 and $20 \%$ were tested in a four stroke, single cylinder, diesel engine at a constant speed of $1500 \mathrm{rpm}$ and variable loads. Comparison of performance characteristics such as fuel consumption, specific fuel consumption, thermal efficiency, exhaust gas temperature, volumetric efficiency and air- fuel ratio for D100, B10 and B20 were investigated. Exhaust emissions concentrations such as $\mathrm{CO}, \mathrm{CO}_{2}, \mathrm{NO}_{\mathrm{x}}, \mathrm{HC}$ and $\mathrm{O}_{2}$ of B10 and B20 were compared to diesel oil. Experimental results of biodiesel blends compared with diesel fuel showed that:

- $\quad$ Diesel- biodiesel blends showed increase in fuel consumption due to the lower heating value of the biodiesel. B20 and B10 showed an increase of 2.6 and $1.4 \%$, respectively in fuel consumption compared to diesel fuel. Biodiesel blends B20 and B10 showed increase in specific fuel consumption about 2.2 and $1.3 \%$, respectively in comparison with diesel fuel.

- $\quad$ Biodiesel blends B20 and B10 showed decrease in engine thermal efficiency about 3.5 and $2.5 \%$, respectively in comparison with diesel fuel.

- Volumetric efficiency for B10 and B20 achieved reductions of 3.5 and 8\%, respectively and air- fuel ratio for B20 and B10 had reductions of 4.5 and $11 \%$, respectively compared to diesel fuel.

- $\quad$ The exhaust gas temperature increased with the operation of biodiesel blends about diesel fuel. Biodiesel blends B20 and B10 and diesel fuels recorded about 380, 370 and $355^{\circ} \mathrm{C}$ of exhaust gas temperatures.

- $\quad$ At full load, the values of $\mathrm{CO}_{2}$ emissions for diesel, B10 and B20 fuels were 6.5, 6.3 and $6.2 \%, \mathrm{NO}_{\mathrm{x}}$ emissions values were 625,630 and $650 \mathrm{ppm}$, respectively.

- At full load, the maximum values of HC emission for diesel, B10 and B20 fuels were about 32, 27 and $23 \mathrm{ppm}$, respectively.

- $\quad$ The maximum increase of oxygen concentration for B20 and B10 in comparison with diesel fuel was about 1 and $3 \%$. 
- Using neat waste cooking oil biodiesel in conventional diesel engine is not recommended. Performance and emissions of a diesel engine using biodiesel blends up to $20 \%$ with diesel fuel were closer to diesel fuel, so waste cooking oil biodiesel blends can be used up to $20 \%$ with diesel fuel without any engine modifications.

- Waste cooking oils are very suitable as low cost feed stocks for biodiesel production. The environment will be cleaned by collecting and recycling these waste oils, human health will be protected and reducing the dependency on fossil fuel resources.

\section{References}

[1] Behcet R., Yumrutas, R., and Oktay, H., Effects of fuels produced from fish and cooking oils on performance and emissions of a diesel engine", Energy, 2014, Vol.71, pp.645-655.

[2] Abu-Jrai, A., Yamin, J.A., Al-Muhtaseb, A.H. and Hararah, M. A., "Combustion characteristics and engine emissions of a diesel engine fueled with diesel and treated waste cooking oil blends", Chemical Engineering Journal, 2011, Vol.172, pp.129-136.

[3] Muralidharan, K., Vasudevan, D.,"Performance, emission and combustion characteristics of a variable compression ratio engine using methyl esters of waste cooking oil and diesel blends", Applied Energy, 2011, Vol.88, pp.3959-3968.

[4] Lin, Y.C., Hsu, K.H. and Chen, C.B., "Experimental investigation of the performance and emissions of a heavy-duty diesel engine fueled with waste cooking oil biodiesel/ultra-low sulfur diesel blends", Energy, 2011, Vol.36, pp.241-248.

[5] Di, Y., Cheung, C. S. ,and Huang, Z.,"Experimental investigation on regulated emissions of a diesel engine fueled with ultra- low sulfur diesel fuel blended with biodiesel from waste cooking oil", Science of The total Environment Journal, 2009, Vol.407, pp.835-846.

[6] Can, O.,"Combustion characteristics, performance and exhaust emissions of a diesel engine fueled with a waste cooking oil biodiesel mixture", Energy Conversion and Management, 2014, Vol.87, pp.676-686.

[7] Enweremadu, C. C., Rutto, H.I.,"Combustion, emission and engine performance characteristics of used cooking oil biodiesel-A review", Renewable and Sustainable Energy Reviews, 2010, Vol.14, pp.2863-2873.

[8] Mohod, T.R., Jikar, P.C., and Khobragade, V.S.,"Experimental Investigation of a Diesel Engine Fueled With Waste Cooking Oil Ethyl Ester", International Journal of Research in Engineering and Technology (IJRET), 2013, Vol.2, No.5, pp.240-244.

[9] Ghobadian, B., Rahimi, H.,Nikbakht, A.M., Najafi,G., and Yusaf, T.F.,"Diesel engine performance and exhaust emission analysis using waste cooking biodiesel fuel with an artificial neural network", Renewable Energy, 2009, Vol.34, pp.976-982.

[10] Sharma, R.B., Pal, A. and Sharaf, J.,"Production of Bio-Diesel from Waste Cooking Oil", Journal of Engineering Research and Applications, December, 2013, Vol.4, No.6, pp.16291636.

[11] Shahid, E.M., Jamal, Y., Shah, a. N., Rumzan, N.and Munsha, M.,"Effect of Used Cooking Oil Methyl Ester on Compression Ignition Engine", Journal of Quality and Technology Management, 2012, Vol.VIII, Issue II, pp.91-104.

[12] Felizardo, P., Correia, M. J.N., Raposo, I., Mendes, J.F., Berkemeier, R. and Bordado, J.M.,"Production, of biodiesel from waste frying oils", Waste Management Journal, 2006, Vol.26, No.3, pp.487-494.

[13] Valente, O.S., Pasa, V.M.D., Belchior, C.R.P. and Sodre, J.R.,"Exhaust emissions from a diesel power generator fuelled by waste cooking oil biodiesel", Science of the Total Environmental Journal, 2012, Vol.431, pp.57-61.

[14] Gopal, K.N.,Pal, A., Sharma, S., Samanchi, C., Sathyanarayanan, K. and Elango, T., "Investigation of emission and combustion characteristics of a CI engine fueled with waste 
cooking oil methyl ester and diesel blends", Alexandria Engineering Journal, 2014, Vol.53, pp.281-287.

[15] Math, M.C., "Performance of a diesel engine with blends of restaurant waste oil methyl ester and diesel fuel", Energy for Sustainable Development, September, 2007, Vol.XI, No.3, pp.93-95.

[16] Hirkude, J.B., Padalkar, A.S.,"Performance and emission analysis of a compression ignition Engine operated on waste fried oil methyl esters", Applied Energy, 2012, Vol.90, pp.68-72.

[17] An, H., Yang, W. M., Maghbouli, A., Li, J., Chou, S. K. and Chua, K.J., "Performance, combustion and emission characteristics of biodiesel derived from waste cooking oils", Applied Energy, 2013, Vol.112, pp.493-499.

[18] Cordiner, S., Mulone, V., Nobile, M. and Rocco, V.,"Effects of Waste Cooking Oil Biodiesel Use on Engine Fuel Consumption and Emissions: a Study on the Impact on Oxidation Catalyst and Particulate Filter", Energy Procedia, 2014, Vol.61, pp.953-957.

[19] Xue, J.,"Combustion characteristics, engine performances and emissions of waste edible oil biodiesel in diesel engine", Renewable and Sustainable Energy Reviews, 2013, Vol.23, pp.350-365.

[20] Muralidharan, K., Vasudevan, D.,"Performance, emission and combustion characteristics of a variable compression ratio engine using methyl esters of waste cooking oil and diesel blends", Applied Energy, 2011, Vol.88, pp.3959-3968.

[21] Adaileh, W.M., AlQdah, K.S.,"Performance of Diesel Engine Fuelled by a Biodiesel Extracted From A Waste Cooking Oil", Energy Procedia, 2012, Vol.18, pp.1317-1334.

[22] Shirneshan, A., "HC, $\mathrm{CO}, \mathrm{CO}_{2}$ and $\mathrm{NO}_{\mathrm{x}}$ Emission evaluation of a diesel engine fueled with waste frying oil methyl ester", Procedia- Social and Behavioral Sciences, 2013, Vol.75, pp.292-297. 